\title{
Accounting
}

\section{Modeling of foreign direct investment impact on economic growth in a free market}

\author{
Oleksandr Samborskyi ${ }^{a}$, Oksana Isai ${ }^{a}$, Iryna Hnatenko ${ }^{b^{*}}$, Olga Parkhomenko ${ }^{a}$, Viktoriia \\ Rubezhanska $^{c}$ and Olena Yershova ${ }^{d}$
}

${ }^{a}$ Kyiv National Economic University named after Vadym Hetman, Ukraine

${ }^{b}$ Kyiv National University of Technologies and Design, Ukraine,

${ }^{c}$ Luhansk Taras Shevchenko National University, Ukraine

${ }^{d}$ Kharkiv Petro Vasylenko National Technical University of Agriculture, Ukraine

\begin{tabular}{l}
\hline C H R O N I C L E \\
\hline Article history: \\
Received May 102020 \\
Received in revised format May \\
152020 \\
Accepted June 152020 \\
Available online \\
June 152020 \\
\hline Keywords: \\
Foreign direct investment \\
Domestic direct investment \\
Economic and mathematical \\
modeling \\
Repatriation of capital \\
Economic growth
\end{tabular}

\section{A B S T R A C T}

\begin{abstract}
The complexity and ambiguity of the contribution of foreign direct investment (FDI) to economic growth necessitates the development of recommendations for the analysis and management of foreign investment flows to maximize their positive impact on the economy and prevent negative consequences. In this regard, the aim of the study is to propose an economic and mathematical modeling of the foreign direct investment impact on economic growth and their interaction with domestic direct investment. The article proposes a classification of factors that determine the inflow of foreign direct investment to developed countries and developing countries. By introducing the external effect of foreign direct investment (capital repatriation), the authors modified the model with foreign direct investment in the form of accumulated foreign capital reserves. An analytical expression is obtained to relate the rate of economic growth to the amount of repatriation depending on the effects of supplementing and substituting foreign direct investment for foreign direct investment.
\end{abstract}

(C) 2020 by the authors; licensee Growing Science, Canada

\section{Introduction}

In a free market, the question of the role of foreign direct investment (FDI) in the economic development of countries has been at the center of the theory of international economics for a long time. FDI involves the organization of new production, the purchase of existing, as well as the creation of joint ventures in a country other than the investor's home country. Acting as a long-term investment, FDI affects economic growth, which is understood as the presence of a long-term trend of increasing production, consumption and welfare of the country. Many researchers share the view that FDI stimulates economic growth in countries both directly (technology and management practices; increase investment resources available to industry; reorientation of consumption from imported products to goods produced by enterprises with foreign capital) and through positive externalities (Kuksa et al., 2019; Hnatenko et al., 2020). At the same time, it is worth emphasizing that in developed countries and developing countries there are slightly different factors that affect the attraction of FDI (Fig. 1). The modern scientific and practical literature actively discusses the principles of the policy of attracting foreign investment and creating a favorable investment climate.

* Corresponding author. Tel.: +380661076939

E-mail address: q17208@ukr.net (I. Hnatenko) 


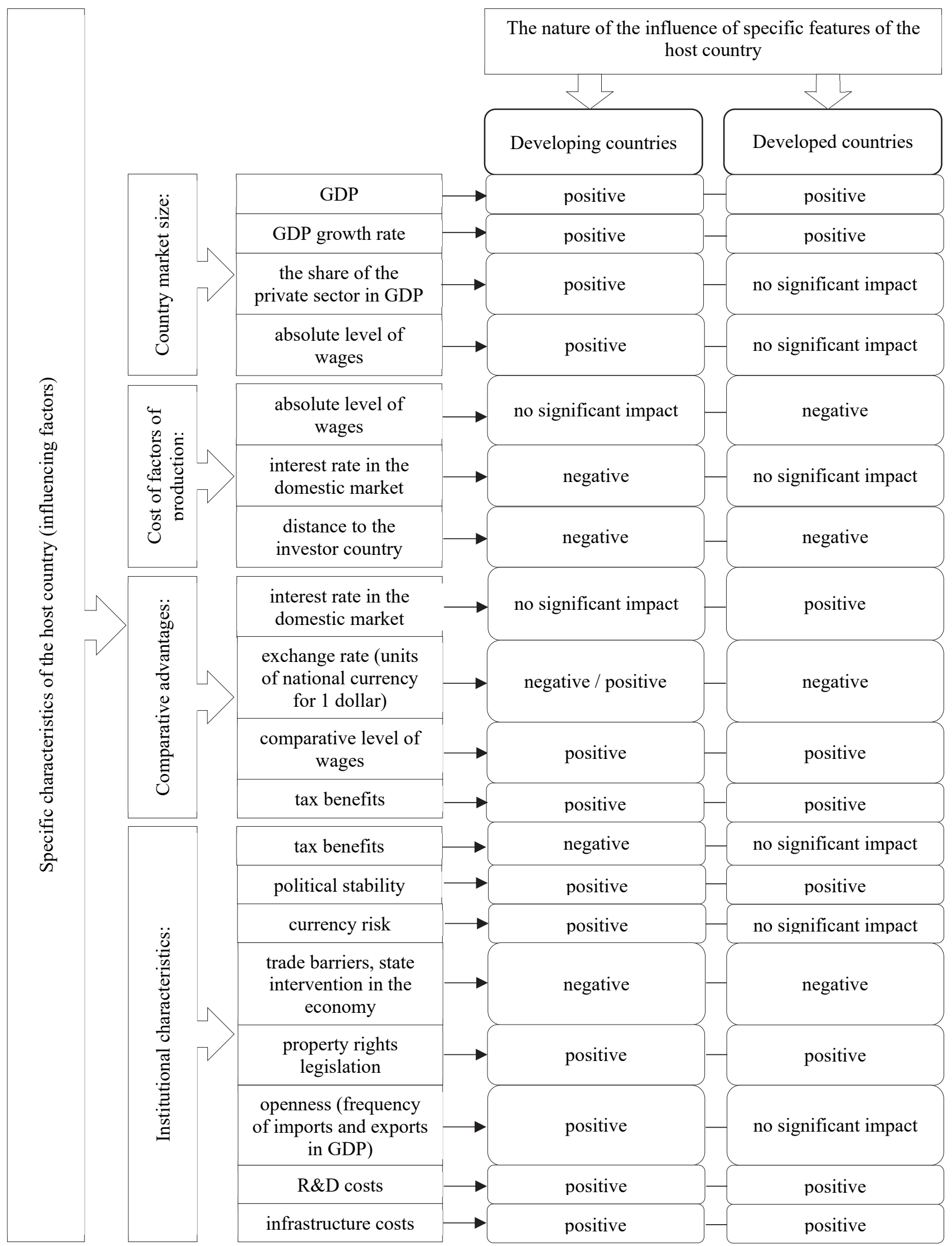

Fig. 1. Classification of factors influencing FDI attraction for developed and developing countries 
However, the complexity and ambiguity of the contribution of FDI to economic growth necessitates the development of recommendations for the analysis and management of foreign investment flows in order to maximize their positive impact on the economy and prevent negative consequences. Thus, in the scientific work Mourao (2018) based on the use of Stochastic Frontier Models found that the dynamic national markets of Africa with a large population and a large forest area are the most attractive for the distribution of foreign direct investment by China. According to the results of the study Mourao (2018), the efficiency of the distribution of foreign direct investment can be maximized by improving political stability and the quality of government regulation, and the effectiveness of government action is an additional factor necessary for this. Griebeler, Wagner (2017) built an economic and mathematical model of the impact of the government's reputation on the level of attracting foreign investment. The study by Lin, Benjamin (2018) examined the relationship between economic growth, energy consumption and foreign direct investment, including the use of a panel dynamic least squares model for Mexico, Indonesia, Nigeria and Turkey, as they are economies, developing countries have a large population and a favorable demographic situation in general. The authors found that there are two-way causal links between economic growth and energy consumption, between economic growth and FDI inflows and one-way causal links between FDI and energy consumption, so scientists recommend diversifying the economy to increase productivity, and excessive dependence on fossil fuels should be minimized (Lin \& Benjamin, 2018). Nishiyama (2017) presents a model of heterogeneity of trading companies and vertical and horizontal FDI. Kahouli, Omri (2017) used a system of gravitational models with a simultaneous equation to study the two-way relationship between trade and FDI in a deteriorating environment. The authors found that the impact of environmental degradation on trade is negative and significant only for static assessment. At the same time, the impact of environmental degradation on FDI is negative and insignificant for both static and dynamic estimates. Delgado et al. (2014) proposed a semi-parametric model that reflects the impact of corruption in the country on FDI inflows. The article found that corruption plays a significant nonlinear role in FDI growth, weakening the effectiveness of FDI in increasing economic growth in developing countries. Ma et al. (2000) analyzed the activities of Japanese multinational corporations in the world economy by building and evaluating the Japanese system of foreign direct investment, which models the determinants of productive foreign direct investment in trade between Japan and its foreign affiliates. The Golubeva study (2020) proposed regression models that show a significant impact of the country's adoption of International Financial Reporting Standards on the level of FDI inflows and returns on foreign investment, depending on the degree of implementation of International Financial Reporting Standards and the level of convergence. Cheng et al. (2020) using the trend score comparison method identified the relationship between the loss of production efficiency due to factor price distortions and Chinese FDI and found that FDI can mitigate the negative impact of factor price distortions on overall productivity of factors of production. Thus, from the point of view of the development of the endogenous growth theory and international capital inflows, research and modeling of the impact of foreign direct investment on economic growth is relevant and important for determining FDI policy in any country, which in turn, confirm the research of the above scientists.

\section{Research methods}

The importance of analyzing the impact of FDI on economic growth is reflected in the presence in the modern scientific and practical literature of a large number of empirical studies of this fact. In addition, there are several theoretical models that to some extent take into account the contribution of FDI to economic growth (Table 1).

It should be noted that theoretical ideas about the role of foreign direct investment are quite narrow. A number of models of endogenous growth consider FDI as a channel for borrowing technological innovations, but in practice, foreign investment flows are not always accompanied by advanced know-how. Moreover, foreign investors sometimes repatriate not only part of the income received from production, but also the invested funds, which can help reduce economic growth. Reinvestment and repatriation of income is an important aspect of any capital inflow.

Some models consider FDI only in the form of accumulated foreign capital reserves, while in the context of rapid technology development and the specifics of FDI investments are made in industries where fixed capital requires constant renewal. Thus, the flow rather than the stock of foreign capital in a country has a greater impact on economic growth. In addition, modern works note that foreign direct investment can lead to negative consequences, in particular, to the displacement of direct domestic investment (DDI). Researchers limit their remarks to the fact that in most cases the degree of influence of FDI on economic growth is higher than DDI and due to this the negative effect of displacement can be compensated. However, a detailed consideration of the interaction between the two types of investment is often beyond analysis and modeling. Thus, the construction of economic and mathematical models that allow the repatriation of income, which consider FDI as a flow of capital to a developing country and take into account the impact of FDI on DDI, is of interest in terms of achieving economic theory adequacy to existing practice. 


\section{Table 1}

The main provisions of economic growth models that take into account FDI

\begin{tabular}{|c|c|c|}
\hline Author, basis & The role of FDI & Conclusions \\
\hline Malley \& Moutos (1994) (neoclassical model) & $\begin{array}{l}\text { FDI is carried out by TNCs, which maximize } \\
\text { profits and choose the area to minimize costs. } \\
\text { Subsidies to TNCs increase economic growth }\end{array}$ & $\begin{array}{l}\text { - increase in tariffs on foreign goods reduces economic } \\
\text { growth; } \\
\text { - a change in FDI affects income levels but not } \\
\text { economic growth }\end{array}$ \\
\hline $\begin{array}{l}\text { De Mello, Luiz (1997) (Barro and Sala-y- } \\
\text { Martin endogenous growth model) }\end{array}$ & $\begin{array}{l}\text { FDI is considered in the form of foreign capital } \\
\text { stock }\end{array}$ & $\begin{array}{l}\text { - increase in foreign capital stock (FDI) has a positive } \\
\text { effect on economic growth; } \\
\text { - in a steady state, economic growth is possible only } \\
\text { through FDI, as the impact of FDI on growth is higher } \\
\text { than the impact of domestic direct investment (FDI) }\end{array}$ \\
\hline $\begin{array}{l}\text { Walz (1997), (model of endogenous } \\
\text { Innovations of Grossman and Helpman) }\end{array}$ & $\begin{array}{l}\text { The presence of a direct effect of FDI - foreign } \\
\text { production of } \\
\text { new products in the host country; } \\
\text { The presence of an external effect of FDI - } \\
\text { imitation of new foreign goods by enterprises of } \\
\text { the host country }\end{array}$ & $\begin{array}{l}\text { - FDI promotes growth through new technologies they } \\
\text { bring; } \\
\text { - discriminatory FDI policies slow down economic } \\
\text { growth in the host country }\end{array}$ \\
\hline $\begin{array}{l}\text { Borensztein et al. (1995), (model of } \\
\text { endogenous growth of Barro and Sala-y- } \\
\text { Martin) }\end{array}$ & FDI is the number of foreign (high-tech) goods & $\begin{array}{l}\text { - FDI increases the pace of introduction of new } \\
\text { products; } \\
\text { - the economies of developing countries are growing } \\
\text { faster than those of developed countries due to savings } \\
\text { on the introduction of new products }\end{array}$ \\
\hline $\begin{array}{l}\text { Fung et al. (1999), (Romer's model of } \\
\text { endogenous technological changes) }\end{array}$ & $\begin{array}{l}\text { FDI is carried out before } \\
\text { industrial and agricultural sectors }\end{array}$ & $\begin{array}{l}\text { - high elasticity of replacement of two types of capital } \\
\text { (domestic and foreign) promotes economic growth } \\
\text { through FDI; } \\
\text { - the direction of FDI flow (to the industrial or } \\
\text { agricultural sectors) does not affect economic growth } \\
\text { under conditions of high elasticity of replacement }\end{array}$ \\
\hline
\end{tabular}

\section{Research results and discussion}

As a basis for building own economic-mathematical model of the impact of FDI on economic growth, the De Mello model was chosen, which takes into account FDI in the form of accumulated foreign capital as opposed to domestic capital.

The modified model uses the following production function (1):

$$
y(t)=A f\left[k_{d}(t), H(t)\right]=A k_{d}^{\beta} H^{1-\beta},
$$

where $y(t)=\frac{Y(t)}{L(t)}$ - productivity per unit of labor;

$A$ - cumulative productivity;

$H$ - technology stock in the country, which depends on the volume of foreign and domestic capital (2):

$$
H(t)=\left[k_{d} k_{w}^{a}\right]^{\eta} .
$$

Let the foreign investor repatriate the capital in the amount $R(t)$ in each period of time. The state can legally limit this level, and can also create incentives for capital reinvestment. In this case, the additional restriction on the trajectory of foreign direct investment consists of the volume of gross FDI less repatriation. The determinant of gross foreign direct investment $(F[H(t)])$ is the level of technology development (formula 2), whereby $\frac{\partial F(H(t))}{\partial H(t)} \geq 0$. Pure FDI is presented as: $k_{w}=F[H(t)]-R$. If $R(t)>F[H(t)]$, then there is a net outflow of foreign capital. Repatriation of capital comes from the inflow of foreign investment and does not affect the stock of domestic capital $R(t) \leq k_{w}(t)+F[H(t)]$. Repatriation of capital does not affect the level of consumption in the current period, however, reduces output in the next period and, accordingly, the level of consumption. In addition, if there is a complete repatriation: $R(t)=k_{w}(t)+F[H(t)]$, production stops because the factors enter the production function multiplicatively (formula 1). In this regard, any non-zero level of repatriation has a negative impact on consumer welfare. Thus, the appearance of the utility function changes, namely: the new function will look like $u(c(t), R(t))$.

The utility function has the usual properties: positive, strictly concave, monotonically increasing in consumption (3):

$$
\begin{aligned}
& \lim _{c \rightarrow 0} u_{c}=\infty \text { and } \lim _{c \rightarrow \infty} u_{c}=0, \\
& \text { where } u_{c}=\frac{\partial u(c, R)}{\partial c} .
\end{aligned}
$$

In the repatriation of capital, the welfare function is negative, strictly convex, monotonically declining (4):

$$
\lim _{R \rightarrow 0} u_{R}=0 \text { and } \lim _{R \rightarrow \infty} u_{R}=-\infty,
$$


where $u_{R}=\frac{\partial u(c, R)}{\partial R}$.

The model, taking into account the proposed modification, is a task of optimal control on the infinite horizon of planning, in which the phase variables are the armament of labor by domestic and foreign capital; control parameters - consumption and repatriation; the target functional is the welfare integral (5):

$\max \int_{0}^{\infty} u[c(t), R(t)] e^{-p t} d t$

provided (6-9):

$k_{d}(t)=A k_{d}^{\beta+\eta(1-\beta)}(t) k_{w}^{\alpha \eta(1-\beta)}(t)-c(t)-n k_{d}(t)$,

$k_{w}(0) \geq 0$,

$\dot{k_{w}}(t)=F[H(t)]-R(t)-n k_{w} t$

$k_{d}(0) \geq 0$,

where $n$ - population growth rate.

The current value of the Hamilton function for Model 1 is presented as (10):

$H a m=u(c, R)+\lambda_{1}\left(A k_{d}^{\beta+\eta(1-\beta)} k_{w}^{\alpha \eta(1-\beta)}-c-n k_{d}\right)+\lambda_{2}\left(F\left(k_{w}^{\alpha \eta} k_{d}^{\eta}\right)-R-n k_{w}\right.$

where $\lambda_{1} \lambda_{2}$ - related variables (economically these are shadow prices of domestic and foreign capital growth, respectively).

According to the Pontryagin maximum principle, optimal control maximizes the Hamiltonian at each time point, then the firstorder conditions are as follows (11-12):

$$
\begin{aligned}
& \frac{\partial H a m}{\partial c}=0 \Rightarrow u_{c}=\lambda_{1}, \\
& \frac{\partial H a m}{\partial R}=0 \Rightarrow u_{R}=\lambda_{2},
\end{aligned}
$$

Thus, the shadow price of capital investment along the optimal trajectories is equal to the marginal utility.

For connected variables (13-14):

$$
\begin{aligned}
& \frac{\partial \text { Ham }}{\partial k_{d}}=-\lambda_{1}+\rho \lambda_{1} \Rightarrow \\
& \Rightarrow A(\beta+\eta(1-\beta)) k_{d}^{\beta+\eta(1-\beta)-1} k_{w}^{\alpha \eta(1-\beta)}-\rho-n+\frac{\lambda_{2}}{\lambda_{1}} F^{\prime} \eta k_{d}^{\eta-1} k_{w}^{\alpha \eta}=-\frac{\lambda_{1}}{\lambda_{1}} \\
& \frac{\partial H a m}{\partial k_{w}}=-\lambda_{2}+\rho \lambda_{2} \Rightarrow \\
& \Rightarrow \frac{\lambda_{1}}{\lambda_{2}} A \alpha \eta(1-\beta) k_{d}^{\beta+\eta(1-\beta)} k_{w}^{\alpha \eta(1-\beta)-1}-\rho-n+F^{\prime} \alpha \eta k_{d}^{\eta} k_{w}^{\alpha \eta-1}-n=-\frac{\lambda_{2}}{\lambda_{2}}
\end{aligned}
$$

Conditions of transversality (15-16):

$$
\begin{gathered}
\lim _{t \rightarrow \infty} e^{-p t} \lambda_{1}(t) k_{d}(t)=0 \\
\lim _{t \rightarrow \infty} e^{-p t} \lambda_{2}(t) k_{w}(t)=0
\end{gathered}
$$

From formulas 11 and 12 the growth rates of related variables are derived (17-18):

$$
\begin{gathered}
\frac{\dot{\lambda_{1}}}{\lambda_{1}}=\frac{u_{c c_{C}}}{u_{c}}, \\
\frac{\lambda_{2}}{\lambda_{2}}=\frac{u_{R R_{R}}}{u_{R}}
\end{gathered}
$$

and the marginal rate of consumption replacement by repatriation, equal to the ratio of shadow prices of foreign and domestic capital (19): 


$$
M R S_{c, R}=\frac{u_{R}}{u_{c}}\left(=\frac{\lambda_{2}}{\lambda_{1}}\right), \quad M R S_{c, R}<0
$$

After substituting formulas (17) - (19) to formulas (13) and (14), implicit expressions are obtained for the optimal trajectories of consumption and repatriation growth (20-21):

$$
\begin{aligned}
& \dot{c}=\frac{-u_{c}}{u_{c c}}\left[A(\beta+\eta(1-\beta)) k_{d}^{\beta+\eta(1-\beta)-1} k_{w}^{\alpha \eta(1-\beta)}-\rho-n+M R S_{c, R} F^{\prime} \eta k_{d}^{\eta-1} k_{w}^{\alpha \eta}\right] \\
& \dot{R}=\frac{u_{R}}{u_{R R}}\left[\rho+n-M R S_{c, R}^{-1} A \alpha \eta(1-\beta) k_{d}^{\beta+\eta(1-\beta)} k_{w}^{\alpha \eta(1-\beta)-1}-F^{\prime} \alpha \eta k_{d}^{\eta} k_{w}^{\alpha \eta-1}\right]
\end{aligned}
$$

For ease of presentation, let the utility function have the following form (22):

$$
u[c(t), R(t)]=\ln (c)-R^{\mu} / \mu
$$

The following notation of the reaction of FDI to changes in domestic and foreign capital, respectively (23-24):

$$
\begin{aligned}
& D\left(\eta, k_{d}, k_{w}\right)=F^{\prime} \eta k_{d}^{\eta-1} k_{w}^{\alpha \eta} \\
& W\left(\eta, k_{d}, k_{w}\right)=F^{\prime} \alpha \eta k_{d}^{\eta} k_{w}^{\alpha \eta-1}
\end{aligned}
$$

Thus, the solution of the proposed model are the optimal trajectories $c^{*}(t), R^{*}(t), k^{*}{ }_{w}(t)$, for which welfare is maximum, satisfying the following conditions (25-28):

$$
\begin{aligned}
& \frac{\dot{\mathrm{c}}}{\mathrm{c}}=M P K_{d}-\rho-n+M R S_{c, R} D\left(\eta, k_{d}, k_{w}\right), \\
& \dot{\frac{R}{R}}=\frac{1}{\mu-1}\left(\rho+n-M P K_{w} M R S_{c, R}^{-1}-W\left(\eta, k_{d}, k_{w}\right)\right), \\
& \dot{k_{d}}=A_{d}^{\beta+\eta(1-\beta)} k_{w}^{\alpha \eta(1-\beta)}-c-n k_{d}, \\
& \cdot \overrightarrow{k_{w}}=F[H]-R-n k_{w}
\end{aligned}
$$

To check the stability of the solution, it is advisable to use a linearized matrix:

if the trace is negative and the determinant is positive, the solution is stable;

if the trace is positive and the determinant is negative - it is the saddle point;

if the trace and determinant are positive - the solution is unstable.

After linearization (25-28) and taking into account:

$\frac{\partial M R S_{c, R}}{\partial c}=\frac{M R S_{c, R}}{c} \quad \frac{\partial M R S_{c, R}}{\partial R}=\frac{(\mu-1) M R S_{c, R}}{R}$

$\frac{\partial M R S_{c, R}^{-1}}{\partial c}=-\frac{M R S_{c, R}^{-1}}{c} \quad \frac{\partial M R S_{c, R}^{-1}}{\partial R}=-\frac{(\mu-1) M R S_{c, R}^{-1}}{R}$

the system is received (29):

$$
\left(\begin{array}{c}
c \\
\cdot \\
R \\
\cdot \\
k_{d} \\
\cdot \\
k_{w}
\end{array}\right)=\left(\begin{array}{c}
c-c^{*} \\
R-R^{*} \\
k_{d}-k_{d}{ }^{*} \\
k_{w}-k_{w}{ }^{*}
\end{array}\right) * \frac{c R}{\mu-1} T
$$

where the matrix $T$ is presented in the form:

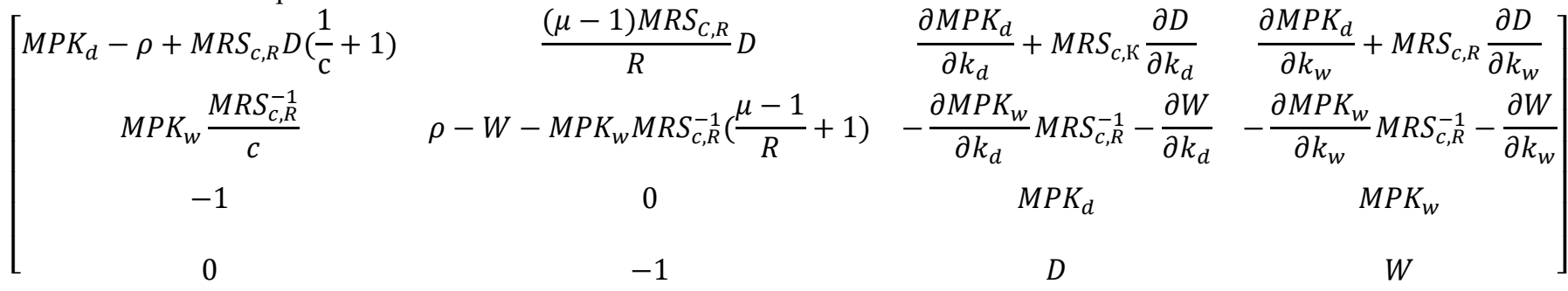


If gross FDI are linear and there is an effect of supplementing domestic investment with foreign $(\eta>0)$, then the exact sign of the determinant of the matrix $T$ cannot be found without additional, cumbersome restrictions. In this case, the optimal trajectories can be both stable and unstable.

If foreign investment displaces domestic investment, the determinant is negative (30):

$$
T=\left[\begin{array}{llll}
+ & + & - & + \\
- & + & + & - \\
- & 0 & + & + \\
0 & - & - & -
\end{array}\right]
$$

The trace of the matrix $T$ is positive (31):

$$
M P K_{d}+M R S_{c, R} D\left(\frac{1}{c}+1\right)-M P K_{w} M R S_{c, R}^{-1}\left(\frac{\mu-1}{R}+1\right)+M P K_{d}>0
$$

Thus, the proposed model, in contrast to the basic model (De Mello, 1997), allows the presence of saddle solutions without limiting the growth rate of consumption.

It is worth noting that by the stationary conditions of the domestic economy $\left(\dot{k_{d}}=0\right)$ the trajectory of economic growth $(g)$ coincides with the trajectory of consumption growth (25): $g=M P K_{d}-(\rho+n)+M R S_{c, R} D\left(\eta, k_{d} k_{w}\right)$. The growth rate of consumption and, consequently, economic growth will be positive if the marginal product of capital exceeds the negative effect of capital repatriation and the sum of the rate of interim utility advantage and population growth rate. The resulting economic growth trajectory is lower than in the de Mello model by the size of the third term (which is negative), which is associated with the possible repatriation of capital, as well as the size of the population growth rate. If the repatriation rate is zero, then the third term is also zero. The third term in the trajectory (25) consists of two parts: $M R S_{c, R}$ and $D\left(\eta, k_{d} k_{w}\right)$. The marginal rate of substitution of consumption for the repatriation of capital shows how much consumption should increase to compensate for the increase in the repatriation of capital by 1 unit, and thus reflects the subjective level of concern about repatriation. The response of gross FDI to direct domestic investment (DDI) shows how much the inflow of FDI will increase (or decrease) with an increase in DDI by 1 unit, i.e. it is an objective component of the negative impact of capital repatriation.

Let foreign capital complement domestic one, then the rate of economic growth slows down at constant levels of domestic and foreign capital, if:

the absolute value of the marginal rate of substitution of consumption for the repatriation of capital increases;

the level of capital repatriation increases;

the intertemporal elasticity of domestic capital substitution by foreign capital increases;

the sensitivity of FDI flow to changes in technology stock increases.

Let foreign capital displace domestic capital $(\eta<0)$, then the marginal product of domestic capital decreases. If $\beta<$ $\frac{\eta}{\eta-1} M P K_{d}$ becomes negative, the growth rate of repatriation of foreign capital increases (all three terms in the trajectory (26) are positive). The sign of economic growth is negative (i.e. there is a drop in output) if (32):

$$
\mid A\left[\beta+\eta(1-\beta)\left(\frac{k_{d}^{1-\eta}}{k_{w}^{\alpha \eta}}\right)^{\beta}|>| c R^{1-\mu} F^{\prime} \eta \mid\right.
$$

In the general case (without optimality and stationarity) in the proposed model, the rate of economic growth is decomposed into components (33):

$$
g_{y}=g_{A}+n+(\beta+\eta(1-\beta)) g_{d}+(\alpha \eta(1-\beta)) g_{w} \text {, }
$$

where $g_{y}, g_{A}, n, g_{d}$ and $g_{w}$ are economic growth rate, growth rate of total productivity, population growth rate, increase in DDI and increase in FDI, respectively.

If $\beta+\eta(1-\beta)>1$ and $\alpha \eta(1-\beta)<1$, then growth is exogenous and is determined by the return, which decreases on domestic capital;

If $\beta+\eta(1-\beta)>1$ and $\alpha \eta(1-\beta)>1$, then long-term growth is explosive;

If $\beta+\eta(1-\beta)<1$ and $\alpha \eta(1-\beta)>1$, then FDI compensates for the decrease in return on the accumulation of domestic capital;

If $\beta+\eta(1-\beta)<1$ and $\alpha \eta(1-\beta)<1$, then growth in the long run is determined by the growth of total productivity factors. If $\beta+\eta(1-\beta)=1,(\eta=1)$, then the impact of foreign capital on economic growth will take shape Eq. (34):

$$
\frac{\partial\left({ }^{y} / y\right)}{\partial k_{w}}=A \alpha(1-\beta) k_{w}^{* \alpha(1-\beta)-1}+\alpha M R S_{C, R} F^{\prime} k_{w}^{\alpha-1}
$$

Thus, in terms of complementing foreign and domestic capital, FDI has a positive effect on economic growth, however, any positive level of capital repatriation reduces its rate. With the displacement of domestic investment by foreign investment, the level of output and consumption almost always decreases. However, such rigid conclusions are sufficiently due to the form of the production function, which assumes that the reduction of foreign capital stock to zero leads to zero output. 


\section{Conclusions}

As a result of the study carried out, it was found that the presence of a positive contribution of foreign direct investment to economic growth depends on their mutual influence with domestic direct investment, as well as the form of investment. The direct effect of FDI can be reduced due to the negative externalities associated with foreign investment, among which are primarily the displacement of domestic investment, repatriation of capital. If foreign direct investment is closely linked to domestic production, their impact on it may depend on the conditions of interaction, both positive and negative. External effects of foreign direct investment, visible at the macroeconomic level, include the addition and displacement of domestic investment, repatriation of capital, repatriation of income, reducing the cost of development and introduction of new products, human capital development and others. These externalities have not been taken into account in endogenous growth models that view FDI as an influx of technology, as technology and human skills cannot be exported, nor can repatriation of management practices. Thus, from the point of view of an individual company, the repatriation of foreign capital, for example, has no special consequences, as it means the sale of this company to a domestic investor, i.e. only a change of ownership. However, from the point of view of the economy of the whole country, the outflow of capital means great negative consequences, as it narrows the amount of investment resources for development in general. Displacement and supplementation of foreign direct investment by foreign is also not critical for the company. Competition between the two types of investment means for the company only that access to finance will be cheaper. Competition between the two types of investment from a macroeconomic point of view leads to the displacement of domestic investment or consumption, which increases dependence on foreign financing, or leads to the outflow of capital from the country, which negatively affects not only economic development but also the socio-political environment.

\section{References}

Borensztein, E., de Gregorio, J. \& Lee, J. (1995). How does foreign direct investment affect growth? NBER Working Paper, 5057.

Cheng, H., Wang, Z., Peng, D. \& Kong, Q. (2020). Firm's outward foreign direct investment and efficiency loss of factor price distortion: Evidence from Chinese firms, International Review of Economics \& Finance, 67, 176-188.

De Mello \& Luiz, R. (1997). Foreign direct investment in developing countries and growth: A selective survey, Journal of Development Studies, 34, 1-34.

Delgado, M., McCloud, N. \& Kumbhakar, S. (2014). A generalized empirical model of corruption, foreign direct investment, and growth, Journal of Macroeconomics, 42, 298-316.

Fung, M., Zeng, J. \& Zhu, L. (1999). Foreign Capital, Urban Unemployment, and Economic Growth, Review of International Economics, 7 (4), 651-664.

Golubeva, O. (2020). Maximising international returns: Impact of IFRS on foreign direct investments, Journal of Contemporary Accounting \& Economics, 16 (2).

Griebeler, C. \& Wagner, E. (2017). A signaling model of foreign direct investment attraction. EconomiA, 18(3), $344-358$.

Hnatenko, I., Orlova-Kurilova, O., Shtuler, I., Serzhanov, V. \& Rubezhanska, V. (2020). An approach to innovation potential evaluation as a means of enterprise management improving, International Journal of Supply and Operations Management, 7(1), 112-118.

Kahouli, B. \& Omri, A. (2017). Foreign direct investment, foreign trade and environment: New evidence from simultaneous-equation system of gravity models, Research in International Business and Finance, 42, 353-364.

Kuksa, I., Shtuler, I., Orlova-Kurilova, O., Hnatenko, I. \& Rubezhanska, V. (2019). Innovation cluster as a mechanism for ensuring the enterprises interaction in the innovation sphere, Management Theory and Studies for Rural Business and Infrastructure Development, 41(4), 487-500.

Lin, B. \& Benjamin, N. (2018). Causal relationships between energy consumption, foreign direct investment and economic growth for MINT: Evidence from panel dynamic ordinary least square models, Journal of Cleaner Production, 197, 708-720.

Ma, Y., Morikawa, K. \& Shone, R. (2000). A macroeconomic model of direct investment in foreign affiliates of Japanese firms, Japan and the World Economy, 12(4), 311-335.

Malley, J. \& Moutos, T. (1994). A prototype macroeconomic model of foreign direct investment. Journal of Development Economics, 43(2), 290-315.

Mourao, P. (2018). What is China seeking from Africa? An analysis of the economic and political determinants of Chinese Outward Foreign Direct Investment based on Stochastic Frontier Models. China Economic Review, 48, 258-268.

Nishiyama, H. (2017). The effect of exchange rate fluctuation on intra-industry reallocation in a firm heterogeneity model with trade and foreign direct investment, The Quarterly Review of Economics and Finance, 64, 32-43.

Walz, U. (1997). Innovation, foreign direct investment and growth. Economica, 64(253), 63-79.

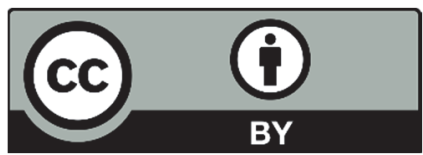

(C) 2020 by the authors; licensee Growing Science, Canada. This is an open access article distributed under the terms and conditions of the Creative Commons Attribution (CC-BY) license (http://creativecommons.org/licenses/by/4.0/). 